\title{
O poczuciu sensu w procesie uczenia się. Casus perspektyw społecznej readaptacji wychowanków Zakładu Poprawczego
}

Celem artykułu jest analiza perspektyw społecznej readaptacji wychowanków Zakładu Poprawczego, ulokowana w szerszym kontekście procesu ludzkiego uczenia się. Na gruncie pedagogiki resocjalizacyjnej w centrum namysłu zawsze ulokowany był podmiot, jednak podejście do niego uległo zasadniczej zmianie: od ujęcia korekcyjno-naprawczego, którego celem było przystosowanie wadliwie socjalizowanych jednostek; do ujęcia, którego istotę stanowi wyzwalanie tkwiących w jednostce społecznie nieprzystosowanej potencjałów. W tym drugim ujęciu ujawnia się edukacyjny kontekst procesu resocjalizacji, polegający na uczeniu się przez wychowanków nowych sposobów społecznego funkcjonowania i kreowaniu nowego kształtu własnej tożsamości. Za najważniejszy element tego procesu uważam zaś nadanie przez wychowanka sensu swojemu wysiłkowi zmiany.

Słowa kluczowe: poczucie sensu, uczenie się, readaptacja społeczna

\section{About the sense of purpose in the learning process. Casus the perspectives of social readaptation of charges of the Correctional Facility}

The aim of the article is to analyze the perspectives of social readaptation of charges of the Correctional Facility, in the broader context of the process of human learning. In the resocialization pedagogy, this subject has always been located in the center of reflection, but the approach to it has fundamentally changed. From a corrective orientation, the aim of which was to adapt the incorrectly socialized individuals; to a take, the essence of which is the liberation of socially maladjusted person's potentials. In this second approach, the educational context of the resocialization process is revealed, which relies on the pupils learning new ways of social functioning and creating a new shape of their own identity. As the most important element of this process, I see the pupil finding purpose in his effort to change.

Keywords: sense of purpose, learning, social readaptation 


\section{Wprowadzenie}

Cechą charakterystyczną badań jakościowych jest ich otwartość i elastyczność, prowadzące czasem do uzyskania dodatkowych danych, które nie leżały w zamyśle badacza i które odsłaniają nieprzeczuwane przez niego obszary ludzkiego myślenia oraz ludzkich doświadczeń. Inspiracją dla powstania tego tekstu jest takie właśnie doświadczenie badacza, poszukującego odpowiedzi na pytanie o interpretacje roli wychowawcy $\mathrm{w}$ procesie resocjalizacji, konstruowane przez wychowanków Zakładu Poprawczego ${ }^{1}$. Analiza przeprowadzonego na potrzeby badania wywiadu fokusowego odsłoniła bowiem mocno eksponowany przez respondentów wątek dotyczący poczucia sensu uczestniczenia przez nich w procesie resocjalizacji. Problematykę tę postrzegam jako kwestię na tyle ważną, choć słabo eksponowaną w pedagogice resocjalizacyjnej, że warto jej poświęcić szczególną uwagę.

\section{Proces resocjalizacji a społeczna readaptacja}

Termin resocjalizacja „ex definitione oznacza ponowną socjalizację, powtórne uspołecznienie, jednostki nieprzystosowanej społecznie, w celu umożliwienia jej poprawniejszego niż do tej pory, funkcjonowania w powszechnie przyjętych i akceptowanych normatywnie rolach życiowych, społecznych i zawodowych. Ma więc to być pozytywna, intencjonalna edukacja spoteczna" [Konopczyński 2014: 13].

W nawiązaniu do tego sposobu definiowania procesu resocjalizacji, na gruncie pedagogiki resocjalizacyjnej zadomowiły się liczne - jak pisze M. Konopczyński - mity resocjalizacyjne. Jeden z nich dotyczy przeświadczenia o tym, że nieprzystosowanie społeczne jest zjawiskiem, które podlega leczeniu czy terapii, dzięki którym możliwe jest wywołanie trwałej zmiany w osobie społecznie nieprzystosowanej [Konopczyński 2014: 14-16]. Mit ten stanowi podłoże ukształtowania się korekcyjno-naprawczej orientacji w pedagogice resocjalizacyjnej, umocowanej w myśleniu medycznym i psychologicznym, dla którego charakterystyczne są praktyki ukierunkowane na diagnozę zaburzenia pod kątem jego etiologii, rozpoznawanie jego przebiegu i na koniec - podjęcie środków zaradczych, swoiste leczenie. Ten "tradycyjny" typ myślenia w resocjalizacji, nazywany integracyjnym, wiąże się z intencją " dokonania korekcji w osobowości i funkcjonowaniu osób nieprzystosowanych społecznie w celu ich dostosowania lub/i przystosowa-

Wykorzystana w tekście wypowiedź pochodzi z wywiadu fokusowego z wychowankami Zakładu Poprawczego w Gdańsku, przeprowadzonego przez Piotra Zająca na potrzeby pracy magisterskiej, której tematyka dotyczyła roli wychowawcy w procesie resocjalizacji w interpretacjach wychowanków. 
nia do oczekiwań bądź wymagań życia społecznego. Hasło integracji społecznej oznacza ostatecznie, że jednostka ma się dostosować/przystosować do otoczenia społecznego" [Szczepaniak 2014: 155-156]. Zdaniem P. Szczepaniaka ten typ resocjalizacji polega na poddaniu osoby społecznie nieprzystosowanej przymusowym oddziaływaniom naprawczym, najczęściej w warunkach społecznej izolacji (ekskluzji). „Taki stan rzeczy opiera się [więc - przyp. M.L-Z] na antynomii: osoby nieprzystosowane społecznie są izolowane od społeczeństwa z zamiarem ich resocjalizacji (...), [zaś - przyp. M.L-Z] hasło integracji społecznej weryfikuje się w społecznej ekskluzji" [Szczepaniak 2014: 156]. W szerszym zaś kontekście ludzkiego uczenia się (w tym przypadku nowych sposobów społecznego funkcjonowania) stanowi on egzemplifikację takiego podejścia do uczenia się, które polega na swoistym „,́wiczeniu na sucho", w warunkach odmiennych od tych, w których przyjdzie wychowankom nabywane umiejętności czy postawy wykorzystywać.

Do najważniejszych z perspektywy mojego wywodu cech orientacji korekcyjno-naprawczej należy skoncentrowanie uwagi na podmiocie, traktowanym jednak jedynie jako obiekt (przedmiot) korekcyjnych oddziaływań resocjalizacyjnych, $\mathrm{z}$ równoczesnym usuwaniem z pola widzenia faktu, że człowiek jest nie tylko obiektem oddziaływania sił społecznych, ale także aktywnym twórcą samego siebie i swojego środowiska społeczno-kulturowego, kreującym swój świat w mediacji z kulturą i innymi podmiotami.

Poszerzenie pola teoretycznego pedagogiki, jej wzrastająca samoświadomość i radykalne przekształcenia kontekstu społeczno-kulturowego ujawniły fakt, że tradycyjne, korekcyjno-naprawcze ujęcie resocjalizacji nie uwzględnia całej złożoności i uwikłań tego procesu, nie może więc być już w związku z tym zadowalające; i ukierunkowały badaczy tego obszaru na poszukiwanie alternatyw myślowych. Budowane były na podłożu wcześniejszych koncepcji: twórczej adaptacji K. Obuchowskiego, w której nie idzie o proste „dostosowanie człowieka z zaburzeniami zachowania, dewianta, nieprzystosowanego do istniejących standardów i norm społecznych, ale mediowane w interakcjach społecznych" [Pytka 2010: 31]; koncepcji twórczej samodzielności wychowanka Cz. Czapówa, zgodnie z którą istotą resocjalizacji jest samorealizacja człowieka przez wykorzystanie jego talentów i zdolności w procesie jego powtórnej socjalizacji; czy koncepcji kreatywnej profilaktyki społecznej J. Kwaśniewskiego, której istota polega na odwoływaniu się do ludzkich potencjałów w profilaktyce społecznej [Pytka 2010: 31]. Ich znaczenie wiąże się przede wszystkim z odmiennym podejściem do społecznego kontekstu procesu resocjalizacji oraz z przesunięciem zainteresowania z procesu korekcyjno-naprawczego na proces wyzwalania ludzkich potencjałów. Z perspektywy mojego wywodu najistotniejsze zmiany wprowadzają jednak dwie najnowsze koncepcje: pierwsza - zaczerpnięta z obszaru pedagogiki specjalnej koncepcja edukacji inkluzyjnej i druga - 
nawiązująca do jej założeń koncepcja twórczej resocjalizacji M. Konopczyńskiego. W ich kontekście, w dyskursie pedagogiki resocjalizacyjnej zainicjowane zostały zmiany o charakterze paradygmatycznym, polegające na włączeniu w pole namysłu pedagogiki resocjalizacyjnej szerszego (niż poziom wadliwie socjalizującej wychowanka grupy pierwotnej) środowiska społecznego, które może mieć charakter ekskluzyjny bądź inkluzyjny, oraz na przeorientowaniu myślenia z procesu naprawiania na proces rozwoju, co integralnie łączy się z pokładaniem ufności w ludzkich zdolnościach do konstruowania (przekonstruowania) własnej tożsamości.

U podłoża tej zmiany leży przyjęcie takiego katalogu wartości, na którego szczycie jest osoba i godność wychowanka. Będące zaś konsekwencją ich przyjęcia działania mają charakter „re-personalizujący, odsłaniający na nowo «osobę» wychowanka w nowym kontekście społeczno-moralnym" [Pytka 2014: 34]. Ich istotą staje się nie tyle inspirowane ideą adaptacji naprawcze oddziaływanie na wychowanka, ile stymulowanie i wzmacnianie podejmowanych przez niego działań o charakterze edukacyjnym. W nawiązaniu do nich readaptacja społeczna, będąca celem działań resocjalizacyjnych nabiera sensu szerszego i odmiennego, niż tylko dostosowanie się do określonych norm społecznych i staje się, jak pisze L. Pytka, również procesem społecznego uczenia się respektowania szczególnych potrzeb i możliwości osób społecznie wykluczonych, które produkuje społeczna struktura, a także edukacyjnym co do zasady procesem konstruowania na nowo własnej tożsamości przez osoby społecznie nieprzystosowane [Pytka 2010: 31].

\section{Ku inkluzji osób społecznie nieprzystosowanych}

Problematyka inkluzji, zdaniem I. Chrzanowskiej, pojawiła się na gruncie pedagogiki i pedagogiki specjalnej w związku z przekształcaniem się społeczeństwa przemysłowego w społeczeństwo wiedzy. W rezultacie tej zmiany coraz bardziej jasne stawało się to, że „[w]spółcześnie potrzebna jest edukacja dostosowana do indywidualnych oczekiwań i potrzeb ludzi, edukacja treściowo elastyczna i tkwiąca w życiowych sytuacjach. Tendencje te stały się podstawą zmiany spojrzenia na edukację podmiotową, której celem miała się stać realizacja hasła edukacji dla wszystkich" [Chrzanowska 2014: 2]. W tym kontekście osoby z niepełnosprawnością stały się pełnoprawnymi członkami wspólnoty ludzi uczących się, a edukacja inkluzyjna zaczęła być traktowana jako narzędzie zapobiegania ich stygmatyzowaniu, wykluczaniu, marginalizacji. Pojęcie kształcenia inkluzyjnego nie doczekało się jednak jednoznacznej definicji. „Często traktowane jest ono 
synonimicznie z terminem integracja, czasami zaś rozumiane jest jako kolejny, wyższy etap w drodze do normalizacji sytuacji nie tylko edukacyjnej osób niepełnosprawnych" [Chrzanowska 2014: 3]. Tymczasem integracja odnosi się do „włączania” ucznia ze specjalnymi potrzebami edukacyjnymi, polegającego na przygotowaniu (dostosowaniu) go do zwykłego środowiska szkolnego, opartym na idei tolerancji, natomiast inkluzja dotyczy uznania prawa każdego ucznia do uczenia się w zwykłej szkole, opartego na akceptacji [Lechta 2010]. Obecnie, na gruncie pedagogiki specjalnej, zagadnienie inkluzji pojawia się nie tylko w kontekście problematyki szkoły czy polityki edukacyjnej, ale również w kontekście szeroko rozumianej przestrzeni społecznej i kulturowej, w której identyfikowane są istniejące bariery i projektowane możliwości pełnego uczestniczenia wszystkich ludzi w życiu społecznym.

Na gruncie pedagogiki resocjalizacyjnej u podłoża idei inkluzji leży przetransponowanie wypowiedzi M. Grzegorzewskiej „nie ma kaleki, jest człowiek”, na zasadę „nie ma przestępcy, jest człowiek” [Pytka 2010: 31]. W jej kontekście „[i]nkluzja to etos w postępowaniu resocjalizacyjnym rozumianym jako akceptacja różnorodności, w takim razie cenienie odmienności nawet osób zdemoralizowanych czy zwichniętych socjalizacyjnie. Nie chodzi tutaj o akceptację lub tolerowanie zachowań destrukcyjnych, w życiu społecznym nie można się zgodzić na dowolność postępowania, lecz o akceptację na poziomie personalnym, gdzie następuje odróżnienie osoby od tego, co ta osoba czyni” [Sobczak 2009: 8].

Resocjalizacja inkluzyjna oznacza w tym ujęciu położenie akcentu na organizowanie środowiska społecznego w taki sposób, żeby „rozbrajać” istniejące mechanizmy stygmatyzowania, wykluczania i społecznej izolacji osób społecznie nieprzystosowanych. Zakres zagadnień poruszanych przez pedagogikę resocjalizacyjną w związku z ideą inkluzji „dotyczy regulacji stosunków społecznych w szerszym kontekście niż poprzez politykę karną, penitencjarną, czy socjalną [...] chodzi o formowanie społeczeństwa otwartego" [Szczepaniak 2014: 162] na zróżnicowane formy odmienności. Stąd „[r]eedukacja inkluzyjna to coś więcej niż reintegracja społeczna. Ta pierwsza wymaga zmiany społecznej w skali makro, by osiągnąć zadowalające wyniki w skali mikro, czyli na poziomie jednostek ludzkich i grup ludzkich z trudnościami adaptacyjnymi. Ta druga wspiera się ideą poprawy, psychokorekcji i wrastania w niechciane niekiedy role społeczne" [Pytka 2010: 32]. Można zatem mówić o tym, że inkluzja oznacza tu „[p]przywracanie [jednostkom i - przyp. M.L-Z] grupom społecznie naznaczonym i marginalizowanym prawa do pełnej partycypacji w życiu społecznym, obywatelskim i kulturalnym" [Pastwa-Wojciechowska 2010: 110].

Popperowska koncepcja społeczeństwa otwartego (typu inclusive), do której nawiązuje P. Szczepaniak, eksponuje takie jego cechy, jak: brak barier dla społecznej ruchliwości, mobilność poziomą i pionową, brak strukturalnych i prawnych 
mechanizmów izolacji i wykluczania społecznego [Popper 1993: 291]. Autor tej koncepcji jest skłonny wiązać powstanie społeczeństwa otwartego z rozpadem zamkniętego społeczeństwa plemiennego, opartego na licznych podziałach i barierach, i dojściem do głosu jednostkowego interesu i indywidualnej inicjatywy. Dzięki nim, człowiek zaczął bowiem sam decydować o tym, co chce robić, uwolnił się od wszelkich form predestynacji i prób instrumentalizowania go, a jego egzystencja zaczęła być traktowana jako wartościowa sama w sobie [Lewartowska-Zychowicz 2010: 48]. Użyteczność przywołanej przez P.Szczepaniaka koncepcji społeczeństwa otwartego wydaje się mieć jednak coraz bardziej ograniczony charakter w świetle licznych opracowań, które wskazują na segregacyjny i wykluczający charakter współczesnej kultury neoliberalnej i przekształcenie się demokracji liberalnej $\mathrm{w}$ demokrację rynkową, $\mathrm{z}$ jej fundamentalizmem rynkowym generującym liczne nierówności i nowe mechanizmy wykluczania [Harvey 2008; Dowbor 2009; Hardy 2010]. W tym kontekście znamienne są cytowane przez Jeana Zieglera słowa Jacquesa Rouxa; „wolność jest jedynie pustym słowem, jeśli jedna grupa ludzi może bezkarnie głodzić inną grupę. Równość jest jedynie pustym słowem, jeśli bogacz, korzystając z prawa monopolu, staje się panem życia i śmierci innego człowieka" [Roux 1793, cyt. za Ziegler 2011: 36].

Postępujące $\mathrm{w}$ związku z tymi kierunkami rozwoju kultury rozwarstwienie i ubożenie społeczeństw powoduje wzrost barier $\mathrm{w}$ dostępie do edukacji i udziału w życiu publicznym, odłączanie się deprywowanych kulturowo podklas, skupionych w obszarach bez wstępu i bez dróg wyjścia. Ich szanse na inkluzję wraz z kolejnymi falami neoliberalizacji zdają się być coraz bardziej ograniczone [Lewartowska-Zychowicz 2014: 162-163]. W tym kontekście projekt resocjalizacji inkluzyjnej może natrafiać na bariery trudne do pokonania, bronione przez potężne siły ekonomiczne, które działają na rzecz segregacji i wykluczania. Dlatego w projekcie tym kluczowe jest nie tylko działanie na rzecz zmiany społecznej świadomości, ale również tworzenie przestrzeni dla dokonania się zmiany $\mathrm{w}$ osobie społecznie nieprzystosowanej. Nie idzie tu już jednak o działania korekcyjno-naprawcze akcentujące zadanie adaptacji społecznej, ale o mocniejsze akcentowanie idei „podmiotowego włączania się osób odczuwających problemy w społecznym funkcjonowaniu i wyrażania ich suwerennego prawa do podjęcia (rozwiązania) tych problemów (z intencją włączenia się do naturalnego nurtu życia społecznego) [Szczepaniak 2014: 150]. Model ten jest wykorzystywany od dawna na gruncie pracy socjalnej, a na terenie resocjalizacji jedna $\mathrm{z}$ jego odmian jest znana pod nazwą probacji, traktowanej jako środek resocjalizacji oparty na społeczeństwie, bazujący na założeniu o większej skuteczności sankcji w warunkach środowiska, niż w warunkach izolacyjnych [Bałandynowicz 2009: 12]. Sam fakt wykonywania sankcji $w$ warunkach wolnościowych nie rozwiązuje jednak kwestii podmiotowych praw osób społecznie nieprzystosowanych, potrzebny 
jest zatem kolejny element, jakim jest uruchomienie się potencjałów edukacyjnych jednostki.

\section{Twórcza resocjalizacja jako projekt inkluzyjny}

Idea twórczej resocjalizacji, wprowadzona do pedagogiki resocjalizacyjnej w latach dziewięćdziesiątych przez M. Konopczyńskiego [1996] jest koncepcją umocowaną $\mathrm{w}$ „odmiennej od dotychczas przyjmowanych perspektyw teoretyczno-metodycznych - naukowej perspektywy poznawczej, traktującej tego rodzaju działalność jako proces zmiany kreującej, a nie proces przymusu zmiany lub zmiany dobrowolnej pod wptywem terapii, charakterystycznych dla dotychczasowej praktyki penitencjarnej, opartej na dorobku klasycznych koncepcji i teorii kryminologicznych, psychologicznych, socjologicznych i pedagogicznych. Podstawą teoretyczną nowego rozumienia istoty działalności resocjalizacyjnej są adaptowane do tej przestrzeni interdyscyplinarne koncepcje interakcyjne, kognitywne oraz koncepcje wynikające z dorobku psychologii i pedagogiki twórczości, a szczególnie współczesne teorie heurystyczne" [Konopczyński 2014: 18]. Koncepcja twórczej resocjalizacji nie stanowi opozycji dla tradycyjnie rozumianego wychowania resocjalizującego, jednak różni się od niego zasadniczo sposobem interpretowania pojęcia nieprzystosowania społecznego (nieprzystosowanie jako problem wadliwie ukształtowanej tożsamości, a nie wadliwych postaw, przekonań i nastawień, patologicznych cech i preferencji); sposobem ujmowania procesu resocjalizacji (resocjalizacja jako proces rozwijania potencjałów, a nie korekcyjna zmiana parametrów społecznych i osobowych); sposobem formułowania celu procesu resocjalizacji (celem procesu resocjalizacji jest kreowanie nowych tożsamości, a nie korektywna zmiana przekonań, nastawień, postaw, czy ról społecznych); definiowaniem drogi prowadzącej do tego celu (rozwój strukturalnych czynników i mechanizmów procesów poznawczych i twórczych, zamiast siłowej zmiany wadliwych form funkcjonowania społecznego za pośrednictwem antropotechnicznych oddziaływań wychowawczych) [Konopczyński 2014: 19].

W koncepcji twórczej resocjalizacji kluczowe znaczenie zyskuje continuum twórczość-resocjalizacja-tożsamość, w kontekście którego osiowy dla wszelkich działań staje się podmiot, jego potencjały oraz tożsamość. Nowe ujęcie orientacji podmiotowej, która sama w sobie nie jest przecież nowym zjawiskiem w pedagogice resocjalizacyjnej, wyraża się w skoncentrowaniu uwagi na tym co jeszcze nieukształtowane, nieuruchomione, a nie na tym co niepożądane w osobowości i funkcjonowaniu człowieka. Efektem aktywności twórczej „rozumianej jako 
zmodyfikowane funkcjonowanie strukturalnych czynników procesów poznawczych osób nieprzystosowanych społecznie jest (...) innowacyjny, twórczy sposób rozwiązywania sytuacji problemowych" [Konopczyński 2014: 21]. Aktywność twórcza, uruchamiająca nowe potencjały w osobie nieprzystosowanej społecznie sprzyja bowiem kreowaniu u niej odmiennego od dotychczasowego stosunku do otaczającej rzeczywistości społecznej i napotykanych problemów, które zaczynają się jawić jako wyzwania, sytuacje problemowe, których rozwiązanie jest możliwe.

Jak pisze M. Konopczyński, w twórczej resocjalizacji idzie o to, że dzięki aktywności twórczej „[w]ychowankowie sami współtworzą i wypełniają treścią ramy swojej nowej tożsamości" [Konopczyński 2014: 21]. Ich wysiłek ma jednak złożony charakter, ponieważ polega na rozstaniu się z przeszłością, zmodyfikowaniu stanu aktualnego i wykreowaniu przyszłości. Pierwszy element wymaga zrozumienia dotychczasowych zachowań oraz ich osobistych i społecznych konsekwencji; drugi „polega na intelektualnym i emocjonalnym włączeniu się w działania rozwijające strukturalne czynniki i mechanizmy procesów poznawczych" [Konopczyński 2014: 21-22]; trzeci natomiast dotyczy „inicjowania procesu społecznego adaptowania własnych form aktywności opartych na ujawnionych potencjałach" [Konopczyński 2014: 22].

Clou tej koncepcji jest ujmowanie procesu resocjalizacji jako procesu inicjowanej $\mathrm{w}$ toku uczenia się zmiany rozwojowej, a nie procesu naprawczego uspołeczniania. Do podstawowych walorów tego ujęcia należy wprowadzenie do pedagogiki resocjalizacyjnej nowego języka, a w szczególności terminu zmiana rozwojowa, który nie jest obciążony pejoratywnym zabarwieniem przypisywanym pedagogicznym działaniom adaptującym podmioty do danego porządku społecznego; oraz ulokowanie procesu resocjalizacji w kontekście ludzkiego rozwoju, co sytuuje w centrum namysłu jednostkę i jej osobisty wysiłek zmiany, a przede wszystkim eksponuje autoedukacyjny moment procesu resocjalizacji, uwalniając ją od korekcyjno-naprawczego piętna. Ma to szczególne znaczenie w kontekście wyzwalania procesu rozwoju nowej tożsamości osób nieprzystosowanych społecznie, bo - jak pisze M. Konopczyński: „[t]ożsamości nie da się zmienić »na siłę«. Jest ona odporna na stosowanie przymusu i karanie. Zmienia się, jeśli dostrzeżemy i rozwiniemy u osoby resocjalizowanej jej »mocne« strony - potencjały, a ona sama uwierzy, że może być akceptowana przez innych ludzi" [Konopczyński 2014: 23].

Jak widać M. Konopczyński wiąże sens swojego projektu z osadzonym w polu edukacji wewnętrznym rozwojem i wykreowaniem nowej tożsamości przez wychowanków, którzy dzięki temu mogą włączyć się w zwykły nurt życia społecznego, porzucić życie na jego marginesie i zdjąć z siebie piętno. Resocjalizacja twórcza ma więc sens inkluzyjny, ale konstytutywne jest dla niej nadanie przez wychowanków sensu własnemu wysiłkowi: 
Ja muszę wiedzieć, że to ma sens, że wszystko, co się tutaj dzieje, co robię ma sens, że mam na coś wpływ, że będę sam robił. Nie wiem, czy dam radę tam na zewnątrz, czy to się uda, ale teraz chcę sam to ogarnąć.

Ja nie mam możliwości, żeby wrócić i inne życie. Zawsze będę miał nasrane w papierach, tu nic się nie zmieni, ale ja muszę sam zobaczyć, czy da się inaczej. Wtedy to będzie miało sens.

Ja właściwie nigdy nic sam nie decydowałem, zawsze tak jak moi kumple. Teraz, jak wyjdę, to oni są w tym samym miejscu, a ja już wiem, że można inaczej. To mi do głowy nie przyszło, bo ja nie znałem innego. Teraz to może i jest sens. Może i warto.

\section{Poczucie sensu - teoretyczne perspektywy analizy}

Przedstawiciele nauk humanistycznych (filozofowie, językoznawcy) odnoszą zwykle pojęcie sensu do kategorii znaku i znaczenia i wówczas wyróżniają "sens logiczny, kulturowy, językowy i poznawczy” [Płoszczyniec 2017: 7]. „Sensem logicznym jest elementarna (logiczna) treść wyrażenia lub zdania. Na gruncie logiki sensowne są zdania oznajmujące, którym można przypisać wartość logiczną prawdy bądź fałszu. [...] Sens kulturowy stanowi znaczenie lub zespół znaczeń nadawanych przez członków kultury pewnym przedmiotom, które znaczą coś specyficznego dla członków owej kultury. [...] Sensowne językowo są wszystkie wyrażenia i zbudowane na ich podstawie zdania, które są uznawane wśród użytkowników danego języka. [...] Sens poznawczy stanowią wszystkie doznania, pojęcia, obrazy, wyobrażenia i koncepcje, które służą reprezentowaniu poznawanej rzeczywistości. Sensem poznawczym jest pewien mniej lub bardziej złożony psychiczny «obiekt», w poznawczej przestrzeni mentalnej podmiotu, pełniący funkcje semiotyczne przez organizację globalnego (ogólnego) bądź lokalnego (zrelatywizowanego do «tu i teraz») stanu wiedzy podmiotu" [Płoszczyniec 2017: 8].

Z kolei w naukach społecznych kategoria sensu jest najczęściej używana w znaczeniu teleologicznym. Teleologicznie „[s]sensowne jest, ma sens to, co celowe, wewnętrznie albo zewnętrznie: postępek, akt zmierzający do czegoś - układ celowo skonstruowany" [Elzenberg 1991: 338]. Teleologiczne pojęcie sensu jest przypisywane ludzkiej woli i ludzkim działaniom, które prowadzą do osiągnięcia zmierzonego celu [Płoszczyniec 2017: 9]. W życiu codziennym ludzie używają bowiem pojęcia sensu (sensowności) na oznaczenie działań, co do których mają poczucie, że są one lub mogą być skuteczne.

Z kolei „[p]oczucie skuteczności to sąd jednostki na temat osobistych możliwości spełnienia różnych warunków zadania, prowadzących do osiągnięcia zamierzonych rezultatów" [Bussey, Bandura 1999: 691, cyt. za Rubacha 2013: 76]. Na ukształtowanie się poczucia skuteczności człowieka mają wpływ czynniki psy- 
chologiczne (odporność na stres i trudności emocjonalne), i czynniki społeczne (jego uprzednie doświadczenia, oceny z jakimi spotyka się ze strony innych, a także obserwowane u innych sukcesy i porażki) [Rubacha 2013: 77]. Poczucie własnej skuteczności jest zmienną, która różnicuje ludzi w zakresie myślenia, odczuwania i działania, „im silniejsze są przekonania dotyczące własnej skuteczności, tym wyższe cele stawiają sobie ludzie i tym silniejsze jest ich zaangażowanie w zamierzone zachowanie nawet w obliczu piętrzących się porażek" [Juczyński 2000: 11].

Problematyka, a w szczególności pomiar, poczucia własnej skuteczności, znajduje się od pewnego czasu w polu zainteresowania pedagogiki resocjalizacyjnej. Badania prowadzone na ten temat dotyczą zaś zwykle kwestii znaczenia poczucia własnej skuteczności z perspektywy potencjału readaptacyjnego osób społecznie nieprzystosowanych, lub metodyki oddziaływania resocjalizacyjnego [por. np. Pastwa-Wojciechowska, Piotrowski 2016; Niewiadomska, Chwaszcz i in. 2014].

W odniesieniu do osób społecznie nieprzystosowanych kategoria poczucia własnej skuteczności nie daje jednak pełnej odpowiedzi na pytanie o posiadane przez nich/możliwe do zaktualizowania potencjały i zasoby readaptacyjne. Ludzkie działanie może być bowiem nieskuteczne, lub podejmujący je człowiek może nie mieć poczucia własnej skuteczności, a jednak podejmuje działania tylko dlatego, że chce i że traktuje je jako sensowne/znaczące, dające wyraz jego przekonaniom. Potwierdzenie tej tezy znajdujemy w licznych udokumentowanych historycznie przykładach, w szczególności tych które odnoszą się do instytucji totalnych i sytuacji ekstremalnych (por. np. akty oporu i bunty więźniów). Dla ich zrozumienia przydatna może być kategoria sprawstwa (agency), która przeżywa obecnie na gruncie socjologii swój renesans i jest jedną z częściej wykorzystywanych kategorii „do analizy działań społecznych i roli tych działań w wytwarzaniu, podtrzymywaniu i transformacji struktur, kultur, instytucji i systemów społecznych" [Leszczyńska 2018: 178]. W podejściach socjologicznych sprawstwo jest odnoszone do tych form aktywności społecznych podmiotów, którym przypisuje się przynajmniej częściową autonomię wobec przymusu społecznego porządku. Z kolei na gruncie pedagogiki sprawstwo jest kategorią, której eksplanacyjny potencjał dotyczy indywiduum - podejmującego działania i dzięki temu dokonującemu zmiany w sobie i w swoim świecie.

Co do swojego znaczenia, sprawstwo jest często traktowane jako kategoria synonimiczna z takimi pojęciami, jak podmiotowość, refleksyjność, czy intencjonalność. „Podmiotowość jest najczęściej interpretowana jako doświadczenie jednostek, odczuwających wpływ na swoje losy i kontrolę nad życiowych planem, gotowych podjąć lub działających intencjonalnie i refleksyjnie" [Leszczyńska 2018: 4]. Sprawstwo przekracza w tym ujęciu horyzont skuteczności działania i obejmuje wszystkie (również nieskuteczne) podmiotowe (autonomiczne, intencjonalne, refleksyjne) inicjowanie działania, których źródłem jest ludzka tożsamość [Iwiń- 
ska 2015: 8]. To - emancypacyjne - podejście do sprawstwa nie obejmuje więc działań wynikających z formalnych reguł, które w istocie nie kontestują wynikających z nich ograniczeń, ani ich refleksyjnie nie transformują. Można nawet powiedzieć, że podtrzymują one status quo [Leszczyńska 2018: 3], a jednak ludzie traktują je jako będące efektem ich decyzji i kontrolowane przez nich. W kontekście tej konstatacji, powiązanie sprawstwa z podmiotowością, intencjonalnością i refleksyjnością nie jest równoznaczne z poczuciem sprawstwa, którego potencjał emancypacyjny może mieć charakter wąski i jednostkowy, nie naruszający społecznych struktur. Pomimo tego, poczucie sprawstwa może być znaczące z perspektywy wyzwalania ludzkich potencjałów, składających się na tożsamość. W kontekście (twórczej) resocjalizacji ukierunkowanej na podmiot konstruujący własną tożsamość na nowo, poczucie sprawstwa staje się ważnym elementem owej tożsamości, chociaż nie musi mieć koniecznie potencjału emancypacyjnego na poziomie strukturalnym. Istotne bowiem w działaniu bywa również to, że podmiot je inicjujący ma poczucie, że jest jego autorem. W kontekście perspektyw społecznej readaptacji osób społecznie nieprzystosowanych idzie więc o to, że uruchamianie ich potencjałów powinno mieć oparcie w ich głębokim przekonaniu o sensowności podejmowanych wysiłków.

\section{Bibliografia}

Bałandynowicz A. (2009), Teoretyczne podstawy probacji, „Probacja”, nr 1.

Bussey K., Bandura A. (1999), Social cognitive theory of gender development and differentiation, „Psychological Review”, no 4.

Chrzanowska I. (2014), Nauczanie inkluzyjne w doświadczeniach polskich - podstawy prawne i społeczne uwarunkowania, „Studia Edukacyjne”, nr 30.

Dowbor, L. (2009), Demokracja ekonomiczna, przeł. Z.M. Kowalewski, Instytut Wydawniczy Książka i Prasa, Warszawa.

Elzenberg H. (1991), Aksjologiczne pojęcie sensu [w:] H. Elzenberg, Z filozofii kultury, Instytut Wydawniczy Znak, Kraków.

Hardy J. (2010), Nowy polski kapitalizm, przeł. A. Czarnacka, Instytut Wydawniczy Książka i Prasa, Warszawa.

Harvey D. (2008), Neoliberalizm. Historia katastrofy, przeł. J.P. Listwan, Instytut Wydawniczy Książka i Prasa, Warszawa.

Iwińska K. (2015), Być i działać w społeczeństwie. Dyskusje wokót teorii podmiotowego sprawstwa, NOMOS, Kraków.

Juczyński Z. (2000), Poczucie własnej skuteczności - teoria i pomiar, „Acta Universitatis Lodziensis", $\mathrm{nr} 4$.

Konopczyński M. (1996), Twórcza resocjalizacja, „Editions Spotkania”, Warszawa.

Konopczyński M. (2014), Twórcza Resocjalizacja. Zarys koncepcji rozwijania potencjałów, „Resocjalizacja Polska", nr 7. 
Lechta V. (2010), Pedagogika inkluzywna [w:] Pedagogika. Podręcznik akademicki, t. 4, B. Śliwerski (red.), GWP, Gdańsk.

Leszczyńska K. (2018), Sprawstwo kobiet w organizacjach katolickich, „Studia Socjologiczne”, nr 2(229).

Lewartowska-Zychowicz M. (2014), Dziecko, kobieta, ubogi-genealogia (neo)liberalnego wykluczenia, "Studia Edukacyjne”, nr 33.

Lewartowska-Zychowicz M. (2010), Homo liberalis jako projekt edukacyjny. Od emancypacji do funkcjonalności, Oficyna Wydawnicza „Impuls”, Kraków.

Niewiadomska I., Chwaszcz J., Augustynowicz W., Bartczuk R. (2014), Readaptacja społeczno-zawodowa więźniów. Narzędzia do diagnozowania potencjału readaptacyjnego i kapitału wspierajacego, Wydawnictwo PiP, Stowarzyszenie NATANAELUM, Lublin.

Pastwa-Wojciechowska B. (2010), Czy pytanie o bezsens resocjalizacji ma sens? , Resocjalizacja Polska", nr 1.

Pastwa-Wojciechowska B., Piotrowski A. (2016), Osobowościowe uwarunkowania skuteczności kadry penitencjarnej, „Resocjalizacja Polska”, nr 12.

Płoszczyniec A. (2017), Czy sens życia jest tym samym co cel życia? Rozważania aksjologiczne, „Analiza i Egzystencja”, nr 37.

Popper R.K. (1993), Społeczeństwo otwarte i jego wrogowie, t. 2: Wysoka fala proroctw: Hegel, Marks i następstwa, przeł. H. Krahelska, PWN, Warszawa.

Pytka L. (2010), Pedagogika resocjalizacyjna w Uniwersytecie Warszawskim. Wczoraj, dziś, jutro, „Resocjalizacja Polska”, nr 1.

Rubacha K. (2013), Uogólnione poczucie skuteczności a poczucie skuteczności wychowawczej rodziców i nauczycieli. Hipoteza sytuacyjnej zmienności, „Studia Edukacyjne”, nr 25.

Sobczak S. (2009), Koncepcja inkluzji w teoriach resocjalizacji jako przeciwdziałanie ekskluzji społecznej, "Student Niepełnosprawny. Szkice i Rozprawy”, nr 9(2).

Szczepaniak P. (2014), Inspiracje inkluzji społecznej dla resocjalizacji i penitencjarystyki, „Profilaktyka Społeczna i Resocjalizacja”, nr 14. 